\title{
PERANCANGAN USER INTERFACE DAN USER EXPERIENCE BRINGHARJO QR SHOP
}

\author{
Ria Andriani ${ }^{1)}$, Fania Ellysabeth ${ }^{2)}$ Jeki Kuswanto ${ }^{3)}$ \\ ${ }^{1,2)}$ D3 Teknik Informatika Universitas Amikom Yogyakarta \\ 3) S1 Teknik Komputer Universitas Amikom Yogyakarta \\ email : ria@amikom.ac.id ${ }^{1}$, fania.el@students.amikom.ac.id ${ }^{2}$,jeki@amikom.ac.id ${ }^{3)}$
}

\begin{abstract}
Abstraksi
UPT. Pusat Bisnis Pasar Bringharjo merupakan pusat pengelolaan kios yang berada di Jl. Margo Mulyo No. 16, Ngupasan, Kec Gondomanan, Yogyakarta, Daerah Istimewa Yogyakarta. Salah satunya fastfood yang berada di lantai tiga pasar Bringharjo Timur. Tempat makan yang terdapat di pasar Bringharjo sendiri masih menggunakan metode manual. Dimana para pengunjung akan mengantri ketika hendak memesan makanan, memilih makanan kemudian membayar total pembelanjaan di meja kasir. Di masa pandemi ini, mengantri sangat rentan dalam penyebaran virus Covid 19 yang sedang melanda dunia, termasuk Indonesia. Tujuan dari perancangan ini ialah untuk menghasilkan desain user interface dan user experience untuk mempermudah pengunjung fastfood pasar Bringharjo dalam bertransaksi, sekaligus membantu mencegah penyebaran Covid19.

Perancangan ini menggunakan metode User-Centered Design (UCD) sebagai proses pemecahan masalah. Metode ini menyesuaikan karakteristik pengguna selama proses perancangan dan diseimbangi dengan konteks serta lingkungan. Selain itu, pengguna berperan dalam mengoperasikan sistem dan menentukan persyaratan yang terdapat pada rancangan user interface dan user experience.

Hasil akhir pada penelitian ini ialah rekomendasi user interface dan user experience aplikasi prototype Bringharjo Qr Shop yang memberikan pengalaman bertransaksi aman dan nyaman bagi pengunjung, serta memenuhi kebutuhan informasi yang pengunjung perlukan.
\end{abstract}

Kata Kunci : User Interface, User Experience dan User-Centered Design

\begin{abstract}
Technical Executive Unit. Central Business BringharjoMarket is the management of a central store located in Margo Mulyo street number 16, Ngupasan, Kec. Gondomanan, Yogyakarta, Special Region of Yogyakarta. Fastfood is one of them which is located on the third floor of the east Bringharjo Market. The fastfood in the Bringharjo market still uses the manual method. Visitors will queue when they want to order food, choose food and then pay for the total purchase at the cashier desk. During this pandemic, queuing is very vulnarable in the spread of the Covid19 virus that is sweeping the world, including Indonesia. The purpose of this design is to produce a user interface and user experience to make it easier for fastfood visitors to Bringharjo market when transacting, while helping prevent the spread of Covid19 virus

This design uses the User Centered Design method as a problem solving process. This method method adapts the characteristics of the user during the design process and is balanced with the context and environment. In addition, user has the role of operating the system and determining the content contained in the design of user interface and user experience.

The final result in this design is a recommendation for the user interface and user experience of the Bringharjo Qr Shop protoype application that provides a safe and comfortable transaction experience for visitors, and fulfills the information needs that visitors need.
\end{abstract}

Keywords : User Interface, User Experience And User-Centered Design 


\section{Pendahuluan}

Di masa pandemi saat ini, tiap individu diharuskan untuk senantiasa menerapkan gaya hidup baru yang disebut new normal. Tatanan baru ini perlu dibiasakan dalam menjalankan produktivitas kegiatan sehari-hari, kebiasaan serta perilaku adaptasi untuk menumbuhkan gaya hidup bersih, sehat serta menjaga jarak. Pandemi ini telah mendorong banyak pelaku usaha untuk berinovasi dalam mengantri. Karena kegiatana mengantri sering kali menciptakan kerumunan yang padat, bahkan menimbulkam barisan yang tidak teratur dan sangat rentan terhadap penularan virus Covid19.

Fastfood yang terletak dilantai tiga pasar Bringharjo Timur merupakan salah satu unit bisnis yang dikelola langsung oleh UPT. Pusat Bisnis Pasar Bringharjo. Restoran ini sendiri masih menerapkan sistem pemesanan manual, yaitu pengunjung bertransaksi dengan cara membuat barisan, memilih makanan yang tertera pada buku menu, menikmati hidangan kemudian membayarnya di meja kasir. Hal tersebut memicu kekhawatiran baik dari pengelola restoran maupun pengunjung, metode tersebut dianggap kurang efektif dalam bertransaksi.

Berdasarkan wawancara yang telah dilakukan kepada pihak UPT. Pusat Bisnis Pasar Bringharjo, fastfood ini memerlukan sebuah website yang memiliki tampilan menarik dan mudah dipahami untuk pengunjung pasar Bringharjo yang berasal dari latar belakang, gender serta usia yang berbeda-beda. Maka, pada penelitian ini akan dilakukan perancangan user interface dan user experience aplikasi prototype Bringharjo Qr Shop. Perihal layanan dan informasi yang tertera pada aplikasi dimulai dari scan qr code atau memberi kode unik yang telah ditentukan oleh pihak pengembang untuk menampilkan menu, harga serta pengunjung dapat bertransaksi pada aplikasi.

Pada penelitian yang dilakukan oleh Bagus Laksono mahasiswa Universitas Dinamika Fakultas Teknologi dan Informatika pada tahun 2021 dengan judul "Evaluasi dan Perancangan User Interface/User Experience Pada Website INMAX Property Menggunakan Model Double Diamond". Pada penelitian ini, berfokus pada evaluasi sebuah website instansi, apakah rancangan user interface dan user experience yang baru dapat mempengaruhi kenyamanan user dengan menggunakan model Double Diamond yang memberikan kebebasan desainer dari batasan dan saat melakukan evaluasi pada suatu desain. Penulis juga menggunakan metode Heuristic Evaluation pada tahap evaluasi. Sedangkan pada penelitian ini, lebih fokus dalam rancangan user interface dan user experience untuk sistem transaksi pada fastfood yang belum memiliki website dengan metode UCD. Metode User Centered Design (UCD) dipilih sebagai proses pemecahan masalah, karena tidak hanya mengharuskan desainer untuk menganalisis dan membayangkan kecenderungan pengguna saat menggunakan suatu produk, tetapi juga memverifikasi asumsi pengguna tentang perilaku mereka di lingkungan. Sehingga menghasilkan rancangan user interface dan user experience untuk aplikasi prototype Bringharjo Qr Shop yang memudahkan pengguna saat bertransaksi.

\section{Metode Penelitian}

Adapun alur penelitian yang digunakan dapat dilihat pada Gambar 1 berikut.

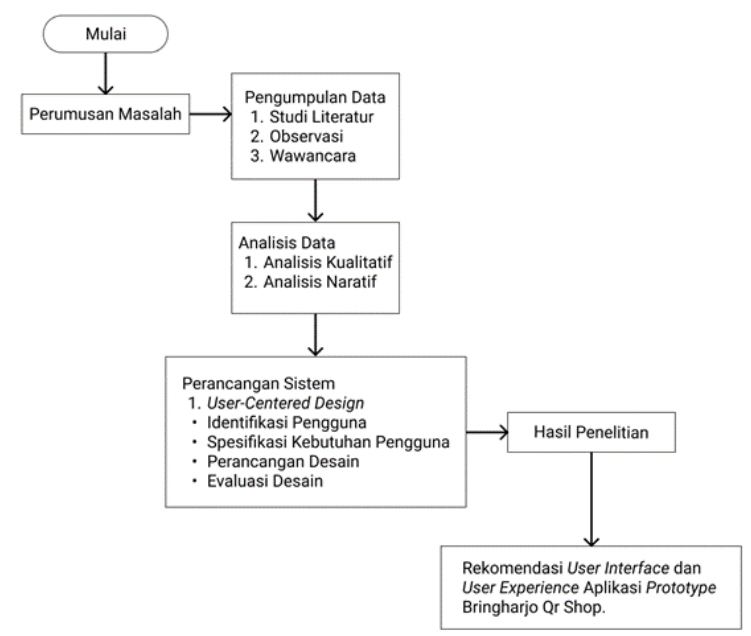

Gambar 1. Alur Penelitian

Penelitian ini terdiri dari beberapa tahapan dimulai dari merumuskan masalah yang ada, kemudian dilakukan pengumpulan data berupa studi literatur, observasi dan wawancara. Untuk analisis data, penulis menggunakan dua metode, yaitu analisis kualitatif dan analisis naratif. Pada rancangan sistem, penulis menggunakan metode User-Centered Design (UCD), yang terdiri dari identifikasi pengguna, spesifikasi kebutuhan pengguna, perancangan desain dan evaluasi desain. Hasil dari penelitian ini berupa rekomendasi user interface dan user experience aplikasi prototype Bringharjo Qr Shop.

\section{Metode Perancangan}

Perancangan merupakan proses penerapan dari teknik yang telah peneliti tentukan sebelumnya. Pada tahap ini elemen dari metode pengumpulan data serta metode analisis di konversikan. Tujuan dari perancangan ini ialah menerapkan data yang telah diperoleh dan dapat di proses agar menghasilkan rancangan user interface dan user experience Bringharjo Qr Shop.

Tahapan yang dilakukan pada perancangan ini ialah daftar pertanyaan, mengidentifikasi calon pengguna, spesifkasi kebutuhan pengguna, perancangan desain, evaluasi desain.

\section{Daftar Pertanyaan}

Peneliti membuat daftar pertanyaan yang diajukan pada proses wawancara agar informasi yang dibutuhkan peneliti saat merancang sistem dapat mencapai tujuan dan data yang diperlukan sesuai 
kebutuhan. Daftar pertanyaan akan dibuat untuk tiga partisipan, meliputi pembeli, pemilik kedai dan pihak UPT. Pusat Bisnis Pasar Bringharjo.

\section{Mengidentifikasi Pengguna}

Peneliti dapat menentukan siapa target pengguna setelah proses wawancara dilaksanakan. Riset calon pengguna diperoleh dari beberapa pertanyaan mengenai keseharian masyarakat dalam hal bertransaksi pada restoran.

\section{Spesifikasi Kebutuhan Pengguna}

Peneliti menggali segala kebutuhan pengguna terkait proses pemesanan serta transaksi bagi para calon pengguna. Pada proses ini peneliti menggunakan metode User-Centered Design (UCD). Fokus metode UCD terletak pada pengguna, kebutuhan serta teknik terkait user.

\section{Perancangan Desain}

Peneliti membuat desain kasaran atau low fidelity dan high fidelity desain visual untuk memastikan tampilan dan warna pada interface sesuai dengan calon pengguna dan tujuan aplikasi. Hasil akhir dari perancangan desain high fidelity ini digunakan untuk prototype interaktif layaknya aplikasi sesungguhnya.

\section{Evaluasi Desain}

Pada tahap evaluasi desain, peneliti menguji coba sistem dengan cara memberikan prototype aplikasi serta memberi tugas kepada calon pengguna untuk bertransaksi menggunakan sistem yang telah dirancang. Feedback partisipan selama sesi akan diperhatikan dan dicatat oleh peneliti sebagai bahan evaluasi desain selanjutnya.

\section{Aplikasi Perancangan}

Peneliti menggunakan aplikasi Figma pada proses perancangan untuk membuat komponen-komponen visual user interface dan user experience aplikasi dalam bentuk grafis vektor. Aplikasi ini juga digunakan peniliti untuk melayout dan membuat prototype desain aplikasi

\section{Metode Analisis}

Metode analisis dilakukan untuk menjelaskan data yang diperoleh saat metode pengumpulan data telah berhasil peneliti kumpulkan. Kegiatan ini dilakukan dengan mengamati, menganalisis serta mengubah data dari hasil penelitian menjadi sebuah informasi baru. Agar data yang diperoleh mudah dipahami dan dapat ditemukan kesimpulan bagi penulis guna merancang user interface dan user experience pada aplikasi prototype Bringharjo Qr Shop dengan menggunakan metode User-Centered Design (UCD).

Metode analisis yang digunakan dalam penelitian ini, yaitu analisis kualitatif dan analisis naratif.

\section{a. Analisis Kualitatif}

Peneliti menjabarkan data yang didapatkan menggunakan analisis kualitatif dan diuraikan dengan kata-kata tertulis dari partisipan yang diamati

\section{b. Analisis Naratif}

Peneliti mengumpulkan serta menganalisis pengalaman pengunjung selama bertransaksi di fastfood pasar Bringharjo Timur, kemudian mendeskripsikan peristiwa menggunakan alur cerita saat penyusunan. Analisis naratif akan membantu menjelaskan dampak dari pengalaman pengunjung, cerita dapat diperoleh dengan metode pengumpulan data yang telah dilakukan sebelumya.

\section{Hasil dan Pembahasan}

Setelah melewati beberapa proses pada tahap analisis serta perancangan, maka diperoleh hasil akhir produk user interface dan user experience aplikasi prototype Bringharjo Qr Shop. Pembuatan desain aplikasi menggunakan Figma. Jumlah layar desain untuk prototype versi mobile Bringharjo Qr Shop sebanyak 26 halaman.

1. Prototyping Scan Qr

Scan Qr merupakan halaman pertama saat user menggunakan aplikasi prototype Bringharjo Qr Shop. Jika pada handphone user tidak ada scan generator.

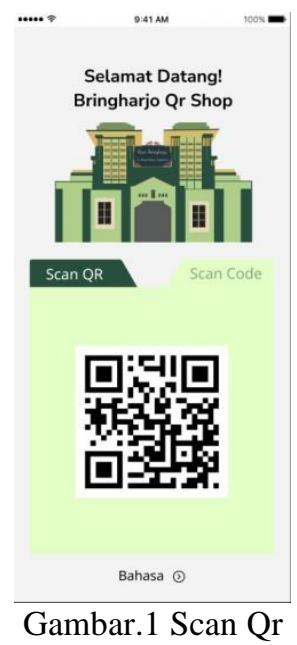

2. Prototyping Scan Code

Tampilan Scan Code berisi inputan kode unik yang telah disediakan pihak pengembang. User mengisi kode dengan benar, lalu memilih ikon "send" untuk melanjutkan ke halaman selanjutnya.

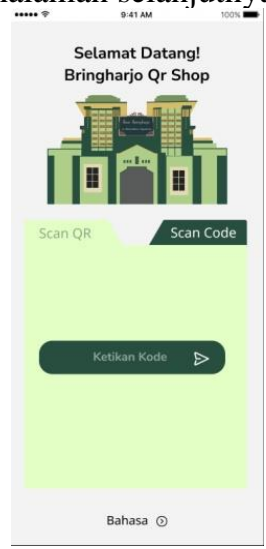

Gambar 2. Prototyping Scan Code

3. Prototyping Data Pengunjung 
Bagian Data Pengunjung berisi inputan yang harus diisi oleh user inputan yang harus diisi oleh user dimulai dari No. Meja yang user tempati, nama pemesan, jumlah tamu serta nomor handphone. Setelah itu user memilih button "kirimkan!" dan akan dialihkan ke halaman berikutnya.

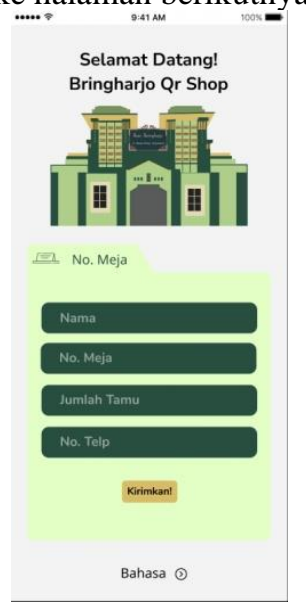

Gambar 3. Prototyping Data Pengunjung

4. Prototyping Beranda

Pada halaman Beranda terdapat inputan pencarian yang berfungsi untuk langsung mencari menu yang user inginkan. Di halaman Beranda user dapat menemukan menu yang direkoemendasikan, restoran favorit di fastfood Bringharjo, serta promo yang tersedia.

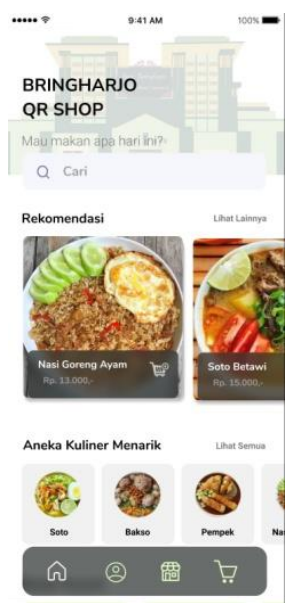

Gambar 4. Prototyping Beranda

\section{Prototyping Profil}

Di halaman Profil berisikan informasi yang sudah di isi oleh user sesudah scan qr atau scan code. Informasi yang tersedia berupa nama pemesan, jumlah tamu dan nomor handphone. Informasi tersebut masih bisa di ubah selama user belum menyelesaikan transaksi.

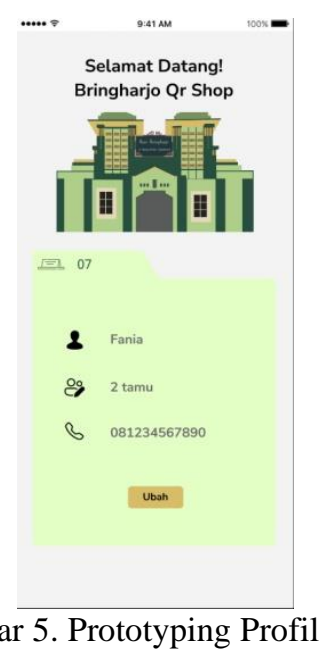

6. Prototypng Detail Pesanan

Halaman Detail Pesanan Anda merupakan bagian yang menampilkan menu yang telah di pilih user dan disertai total yang harus dibayar.

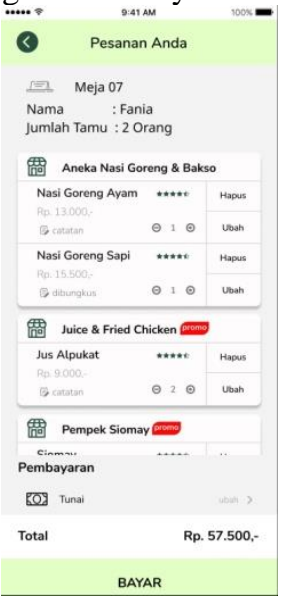

Gambar 6. Prototyping Detail Pesanan

7. Prototyping Metode Pembayaran

Pada bagian Metode Pembayaran, user bisa memilih cara yang mana untuk menyelesaikan transaksi. Pihak pengembang menyediakan dua cara, yaitu qris code dan tunai.

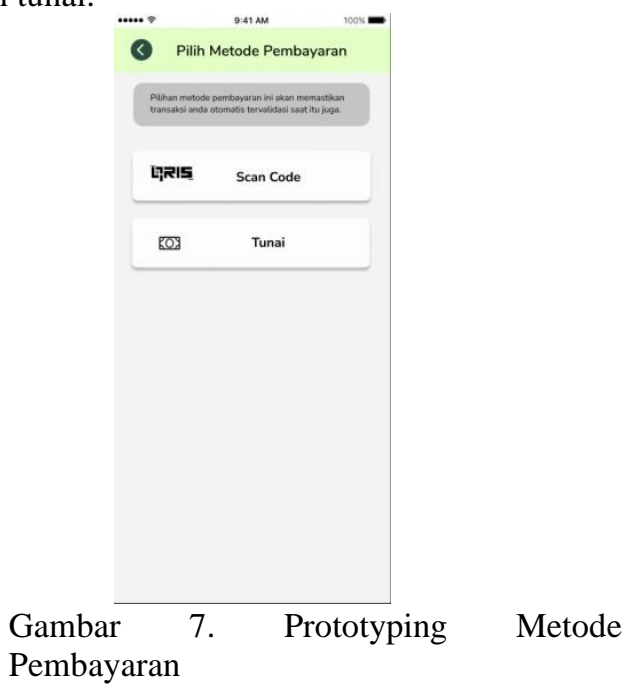




\section{Prototyping Status Pemesanan}

Halaman Status Pemesanan merupakan bagian terakhir interface saat user melakukan transaksi menggunakan aplikasi prototype Bringharjo Qr Shop. Halaman Status pemesanan dijadikan bukti konfirmasi bahwa pesanan sudah diterima oleh penjual dan akan segera diproses.

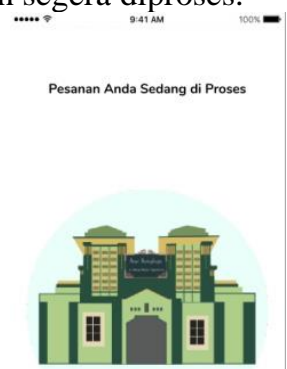

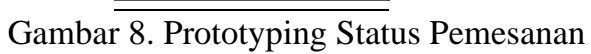

\section{Prototyping List Kedai}

Pada List Kedai, menampilkan nama restoran, jumlah menu hingga rating yang resto dapatkan dari pengunjung lainnya.

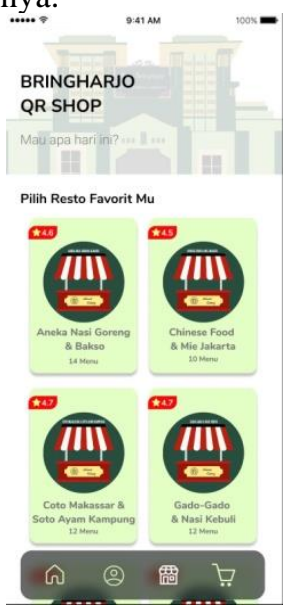

Gambar 9. Prototyping List Kedai

Wawancara yang diilakukan kepada 20 pengguna untuk mengetahui pendapat pengguna mengenai interface yang telah dirancang untuk direkomendasikan kepada pengembang. Berdasarkan jawaban dari user dapat diambil kesimpulan dari jawaban yang paling banyak dilontarkan oleh user. Adapun kesimpulan hasil dari wawancara usability testing adalah sebagai berikut:

1. Semua pengguna berpendapat bahwa interface prototype Bringharjo Qr Shop memiliki desain yang bagus dan warna yang berciri khas.

2. 2 dari 20 pengguna berpendapat belum bisa membedakan antara ikon beranda dan kedai
3. Semua pengguna berpendapat bahwa tugas yang ada memiliki bobot yang sama dan mudah dikerjakan satu per satu.

4. Semua pengguna berpendapat bahwa prototype aplikasi Bringharjo Qr Shop merupakan sistem transaksi yang dibutuhkan pada masa pandemi saat ini dan seterusnya

5. 3 dari 20 pengguna berpendapat bahwa fitur profil yang terdapat di prototype aplikasi Bringharjo Qr Shop kurang maksimal dalam penggunaanya. Selain itu, fitur yang digunakan pada aplikasi sudah memenuhi kebutuhan transaksi bagi user.

\section{Kesimpulan}

Berdasarkan penelitian yang telah dilakukan, maka bisa ditarik kesimpulan sebagai berikut :

1. Tahapan perancangan dilakukan secara digital menggunakan software Adobe Illustration dan Figma. Dalam perancangan user interface dan user experience prototype aplikasi Bringharjo Qr Shop ini disesuaikan dengan target audiens dari fastfood pasar Bringharjo Timur yang telah ditentukan melalui riset dan analisis. Pada konsep perancangan ini memusatkan pengguna sebagai subjek dari pemakai sebuah produk tertentu berdasarkan perilaku mereka atau disebut User Centered Design.

2. Perancangan user interface dan user experience aplikasi prototype Bringharjo Qr Shop ini merupakan upaya untuk memberikan solusi terhadap permasalahan transaksi yang terjadi di tempat penelitian.

3. Pengujian hasil rancangan berupa prototype dilakukan dengan 20 partisipan dari pengunjung fastfood pasar Bringharjo Timur. Dari hasil wawancara usability testing, semua pengguna berpendapat bahwa prototype aplikasi Bringharjo Qr Shop merupakan sistem transaksi yang dibutuhkan saat pandemi maupun untuk berkelanjutan.

Maka, user interface dan user experience aplikasi prototype Bringharjo Qr Shop dinyatakan dapat diterima dengan baik oleh pengunjung dengan memberikan kemudahan serta kenyamanan bagi pengunjung.

\section{Daftar Pustaka}

[1] Ananda, V. P., 2020, Perancangan User Interface (UI) Dan User Experience (UX) Prototype Aplikasi Mobile AIS Menggunakan Metode Lean UX, SKRIPSI, Universitas Islam Negeri Syarif Hidayatullah, Jakarta

[2] Andi, R., 2018, Perancangan Desain User Interface (UI) Aplikasi Pencari Kost, SKRIPSI, Universitas Negeri Makassar, Makassar

[3] Annisa, M., Ismiarta, A., Hanifah, M, A,A., 2019, Perancangan Antarmuka Pengguna Sistem Informasi Prosedur Pelayanan Umum Menggunakan Metode 
Design Thinking (Studi Kasus: Fakultas Ilmu Komputer Universitas Brawijaya , Jurnal Pengembangan Teknologi Informasi dan Ilmu Komputer, e-ISSN: 2548-964X, Vol. 3, No. 4. April, 2019

[4] Arief, M.Rudianto, 2011, Pemrograman Web Dinamis Menggunakan PHP dan MYSQL, Andi Offset, Yogyakarta.

[5] Arief, R. S., 2020, Perancangan UI/UX Menggunakan Pendekatan HCD (Human-Centered Design) Pada Website Thriftdoor, THESIS, Informatika, Universitas Islam Indonesia, Yogyakarta

[6] Bagus, L., 2021, Evaluasi dan Perancangan User Interface/User Experience Pada Website INMAX Property Menggunakan Model Double Diamond, TUGAS AKHIR, Universitas Dinamika, Surabaya

[7] Galitz, Wilbert O, 2007, The Essential Guide to User Interface Design: An Introduction to GUI Design Principles and Techniques, IN: Wiley Publishing, Indianpolis.

[8] George, M.Scot, 2001, Prinsip-Prinsip Sistem Informasi Manajemen, Mc. Graw-Hill, inc, Jakarta.

[9] ISO 9241-210, 2010, Ergonomic of Human-System Interaction - Human-Centered Design for Interactive Systems

[10] Ni, P.V.L.S, A.A, Komplang,O,S, Putu, W.B 2020, Perancangan User Interface dan User Experience SIMRS Modul Akuntansi Keuangan, JITTER-Jurnal Ilmiah Teknologi dan Komputer, Vol 1, No. 2. 2 Desember, 2020

[11] R.P, Hero, W., Herman, T., Hanifah, M, A,A., 2019, Perancangan User Experience Aplikasi Pemesanan Katering Sekolah Dengan Menggunakan Metode Human-Centered Design, Jurnal Pengembangan Teknologi Informasi dan Ilmu Komputer, e-ISSN: 2548-964X, Vol 3, Noo. 3, Maret 2019

[12] Rifda, F.A, Yahya, T.H., 2019, Analisa Usability Desain User Interface Pada Website Tokopedia Menggunakan Metode Heuristics Evaluation, Jurnal TEKNOKOMPAK, ISSN: 1412-9663, Vol.1 3, No. 1., 2019

[13] Yoga, A., 2018, Perancangan Antarmuka Pengguna Dengan Metode Lean UX Pada Website Hello Work Dinas Tenaga Kerja Kabupaten Pasuruan, TUGAS AKHIR, STIKOM Surabaya, Surabaya. 